\title{
THE BILATERAL BINDING CHARACTER OF THE DEBT CONTRACT
}

Kamil M. Arslanov

Kazan Federal University, cand. of Law Sciences, docent, head of department of civil law of Kazan Federal University,

Kazan, (Russian Federation).

E-mail: kamil.arslanov@gmail.com ORCID: https://orcid.org/0000-0001-9703-0908

Artur I. Khabirov

Kazan Federal University, assistant of department of civil law of Kazan Federal University, Kazan, (Russian Federation). E-mail: art.khabir@gmail.com ORCID: https://orcid.org/0000-0002-6491-9070

Recepción: 08/05/2020 Aceptación: 30/06/2020 Publicación: 24/08/2020

\section{Gitación sugerida:}

Arslanov, K.M., y Khabirov, A.I. (2020). The bilateral binding character of the debt contract. 3C Empresa. Investigación y pensamiento crítico, 9(3), 125-137. https://doi.org/10.17993/3cemp.2020.090343.125-137 


\section{ABSTRACT}

The aim of this paper is to investigate the bilateral responsibility character of the loan agreement. At the heart of a research there is a method of the analysis of the existing Russian legislation and law-enforcement practice and the existing European standards for legal unification. Results revealed that the rights of the lessor can be subdivided on precontractual and contractual. The right to reliable information about the borrower belongs to precontract laws of the lessor; right for coordination of contractual conditions. Moreover, it is necessary to differentiate the contract monetary and the contract of a commodity (real) loan in connection with differences in a set of the bilateral rights and duties of the lessor and borrower. In conclusion, in the pre-revolutionary doctrine an opportunity to sign the loan agreement on consensual model in this connection we consider that this legal design can be reproduced in the existing civil legislation was proved.

\section{KEYWORDS}

Loan Agreement, Precontractual, Contractual conditions, Consensual model, Bilaterally Binding Character, Rights of the borrower, Civil legislation. 


\section{INTRODUCTION}

The traditional opinion in science of civil law adheres to a position that "the contents of the loan agreement, proceeding from its unilateral nature, make a duty of the borrower to return the loan sum (Art. 810 of group of companies) and the right of the requirement of the lessor corresponding to it" (Givil law: textbook in 3 t, 2017). Therefore, the borrower has no under the considered contract any rights, and any duties, except an all-creditor duty to accept appropriate execution (Khabirov, 2014). So, for example, Sukhanov pays attention to the so-called creditor duties of the lessor (item 2 of Art. 408 of group of companies) which are available in the majority of obligations and not turning this contract into bilaterally binding. The lessor is obliged to issue to the borrower the voucher of a subject of a loan, or to return the relevant debt document (for example, the receipt of the borrower), or to make record about return of a debt on the returned debt document, or, at last, to note in the receipt impossibility of return of the debt document issued by the borrower (in particular, because of his loss) (Russian civil law: textbook, 2011). Mikhalev and Sofronov emphasize that in loan legal relationship there are no counter duties, doing the reservation that on the lessor so-called creditor obligations for execution acceptance (Art. 406, item 2 of Art. 408 of the Civil Code of the Russian Federation) lie (Civil law: textbook, 2017). Also, Sgibiyeva considers that the loan agreement is unilaterally binding (Givil law: the textbook, 2006). Vitryansky notes that the loan agreement is unilaterally the binding contract that "does not raise doubts and admits all authors" (Braginsky, 2006). Thus, in science of civil law there was an opinion that existence of the counter duties of the creditor in the loan agreement having the general character does not influence unilateral character of this contract. However there is also other position which already found the reflection in science of civil law and which is presented in the real work (Arslanov, 2016; Corbin, 1918; Melo et al., 2018).

\section{METHODS}

At the heart of a research there is a method of the analysis of the existing Russian legislation and law-enforcement practice and the existing European (world) standards for legal unification (Law, 2015). 
Methods of legal modeling and forecasting allow defining need of introduction of amendments to the existing Russian regulations, as well as needing of correction of jurisprudence (Dale, 1977). Thanks to methods of modeling and forecasting can with enough degree of reliability be established a consequence of introduction of such changes and adjustments, as well as it is revealed, how, finally, the Russian law-enforcement practice will be brought closer to the available European (world) standards. The right sociological method allows assessment of social problems from a legal position, from a position of the legislator and the law enforcement official (Siems \& Síthigh, 2012). The method of interpretation supplements the comparative and legal analysis in a research, allowing understanding and comparing the Russian and European (world) legal standards (Davies, 2016: Marandi et al., 2015).

\section{RESULTS}

First, both according to the loan agreement, in general, and under the contract of a consumer loan, in particular, the borrower is given certain rights that allows to draw a conclusion on bilaterally binding character of the loan agreement. The rights of the loan agreement parties can be classified on precontractual and contractual; on the rights connected with emergence, execution and termination of the contract of a loan; on the property and non-property rights. The system of information rights of the borrower is separately allocated; classification of information rights of the borrower is developed and proved.

Secondly, a set of competences of the parties under the contract of a monetary and commodity (ware) loan differs. The volume of competences of the borrower under the contract of a consumer loan differs. Under the contract of a ware loan the borrower has the same rights, as well as the buyer under the contract of purchase and sale in the part relating to the characteristic of the transferred thing (goods) (owing to the corresponding application of Art. 822 of the Civil Code of the Russian Federation).

Thirdly, it is necessary to differentiate the mechanism of protection of the rights of the parties under the contract of a monetary loan and under the contract of a ware (commodity) loan. In case of violation by 
the lessor under the contract of a commodity loan of the corresponding duties, the borrower can protect the rights in not jurisdictional form. Measures of operational impact are applied: refusal of the contract; refusal of acceptance of inadequate execution. Such way of protection as the termination or change of legal relationship, award to discharge of duty in nature is used. Means of protection are the statement, a claim. Under the contract of a monetary loan of the party carry out protection of the rights in law order by means of such security measure as the statement of claim. Therefore, depending on subject of the contract of a loan there are distinctions in shape, means and ways of protection.

The scientific results received during the conducted research allowed to formulate a number of suggestions for improvement of the current legislation. New edition of item 1 of Art. 807 of the Civil Code of the Russian Federation: "According to the loan agreement one party (the creditor, the creditor) transfers or undertakes to transfer to the possession to other party (borrower) the money or other things determined by patrimonial signs, and the borrower undertakes to return to the creditor (creditor) the same sum of money (the loan sum) or equal quantity of other things of the same sort and quality received by it. The loan agreement in which a creditor (creditor) is the citizen and which subject is money is considered concluded after the date of transmission of money". New edition of the offer 2 of item 6 of Art. 7 of the Federal Law "About a Consumer Loan (Loan)" to state in the following edition: "The contract of a consumer loan is considered the prisoner if between the parties of the contract consent according to all individual terms of the contract specified in part 9 of article 5 of the present Federal law is reached".

\section{DISCUSSION}

Meyer (2003) pointed to an opportunity to sign bilaterally binding loan agreement according to which it will be possible to force the lessor to grant a subject of a loan. Karapetov (2012), Vishnevsky (2015), and others also spoke an opportunity to sign the loan agreement on consensual model (Khabirov, 2017). The similar position meets also in jurisprudence (for example: The resolution of Arbitration court of the East Siberian Federal District of March 20, 2016 no. F02-833/16 in the matter of No. A33-6853/2015). It 
is obviously possible to draw a conclusion that is possible to assign an obligation for granting a subject of a loan to the lessor.

By the current legislation the rights are distinguished: 1) the right of the borrower to return the sum of an interest-free loan ahead of schedule and the corresponding duty of the lessor to accept this sum from the borrower; 2) the right to challenge the loan agreement on lack of money of the contract and the duty of the lessor corresponding to this right to accept objections of the borrower or to produce the evidence of "money-part" of a loan (Arslanov, 2016); 3) the right to demand acceptance of appropriate execution; 4) the right to demand to issue it the voucher of execution completely or in the corresponding part, the debt document, and at impossibility of return to point to it in the receipt issued to them.

In that case when a subject of a loan is not money, but other things determined by patrimonial signs there is a question of responsibility of the lessor for quality of the transferred things (Arslanov, 2016). We find it possible to draw a conclusion that rules of article 822 Civil Code of the Russian Federation about quantity, about the range, about completeness, about quality, about a container and (or) about packing of the provided things are subject to application and to the loan agreement of things. It is necessary to agree with Romanets (2013) who points to a possibility of application to separate types of the loan agreement and other norms from the section of hl. 30 Civil Code of the Russian Federation: Art. 455, Art. 456, Art. 457 which do not contradict the nature of the consensual contract of the commodity credit. With Art. 459 of group of companies about transition of risk of casual death of goods, as well as the Art of Art. 460 - 462 groups of companies could add regulation of the relations of the real loan agreement of things (Romanets, 2013).

The wide range of the rights is provided to the borrower according to the Federal Laws "About a Consumer Loan (Loan)" which can be classified by several bases. Let's join classification of Fedulina (2015) according to which division of the rights of the borrower under the contract of a consumer loan (loan) on their character on property (the right for indemnification, caused to the borrower by inadequate performance of obligations under the contract is possible; the right for compensation of the 
size of the paid percent and other payments under the contract of a consumer loan at return of goods of inadequate quality, etc.) and non-property (the right for information, the right for the free choice of the services rendered within the credit (loan) agreement (for example, insurance), etc.).

By analogy with the rights of the consumer granted in the contract of retail purchase and sale, the consumer work it is possible to select precontract and contract laws of the borrower. First, the right for information concerns to the first group of the rights. In literature the importance of those provisions of the legislation which regulate the precontractual relations, namely informing the borrower on terms for crediting is noted (Shvachko, 2012). Often the precipitate conclusion of loan agreements and the credit (including consumer) on enslaving conditions for borrowers is caused by absence in the last full and clear information on terms of the contract and consequences of their violation (a speech of the Russian President V. V. Putin at a meeting of Presidium of the State Council concerning "About National System of Consumer Protection" (Novgorod, 2017)).

The second group of the rights of the borrower relates to execution and termination of the contract of a loan. In particular, treat group of the rights connected with performance of the contract of a consumer loan: the right to use the loan sum as on the definite purposes established in the contract, and at discretion if in the loan agreement the definite purpose is not specified; the right of the borrower to forbid the creditor a concession of the rights (requirements) to the third parties; right for stability of contractual conditions.

Also it is necessary to refer the right of the borrower for observance of conditions of interaction with the creditor to group of the rights connected with execution of the loan agreement (Fedulina, 2015). Respect for this right became very urgent that is connected, first of all with unfair, and, sometimes, and illegal behavior of the persons who are engaged in return of debt as the primary activity (so-called "collectors"). The long time in jurisprudence and the doctrine did not exist unities of opinions on a possibility of a concession of the rights (requirements) for the contract of the credit (Lupu \& Whether, 2011; Khabirov, 2013). Now the given disputes are deprived of the bases since in the law "About a 
Consumer Loan (Loan)" of Art. 12 directly allows such concession (see also Art. 4 of the Federal Law "About protection of the rights and legitimate interests of natural persons at implementation of activities for return of arrears and about introduction of amendments to the Federal law "About Microfinancial Activity and the Microfinancial Organizations").

The borrower within group of the rights connected with performance of the contract has rights for free execution of the liability under the contract of a consumer loan. This right is exercised by obligatory providing free repayment of a debt to the borrower of at least one way (item 19 of Art. 5 of the Federal Law "About a Consumer Loan (Loan)"). Moreover, when opening of the bank account of operation on it provided by the contract must be carried out free of charge (item 17 of Art. 4 of the Federal Law "About a Consumer Loan (Loan)". This competence is designed to protect borrowers from the hidden payments and the commissions (see also subitem 5 of item 5 of Art. 6 of the Federal Law "About a Consumer Loan (Loan)").

It is necessary to refer the right of the borrower for early return of the sum of a consumer loan within 14 days to group of the rights connected with termination of the contract of a consumer loan (30 days when receiving a loan on definite purposes). In literature it is pointed out the importance of fixing of these competences of the borrower (Rybakova, 2012). Thus, the borrower as under the contract of a monetary loan, especially under the contract of a consumer loan, and under the contract of a commodity (ware) loan, it is allocated with the big list of the rights that allows to draw a conclusion on bilaterally binding character of the loan agreement.

The lessor (creditor) according to the loan agreement, a consumer loan also has certain groups of the rights which can be classified by several bases. So, by analogy with the above-stated classification of the rights of the borrower on property and non-property it is possible to mark out the property and nonproperty rights of the lessor. The right to percent for use of a loan, the right to the due percent in case of the compelled early cancellation of the contract because of the violation allowed by the borrower belongs to property rights of the lessor; the right to demand return of the sum of a loan. It is necessary 
to refer the right to information on the borrower, the right for the free choice of the contractor under the contract to the non-property rights of the lessor.

The rights of the lessor can be subdivided on precontractual and contractual. The right to reliable information about the borrower belongs to precontract laws of the lessor; right for coordination of contractual conditions. According to item 3 of Art. 7 of the Federal Law "About a Consumer Loan (Loan)" the creditor considers the application and other documents of the borrower. Within the precontractual relations the lessor (creditor) has the right to refuse delivery of a consumer loan.

\section{SUMMARY}

The loan agreement has bilaterally binding character. Under the contract of a monetary loan the borrower has 1) the right ahead of schedule to return the sum of an interest-free loan, as well as the sum of the loan granted under percent to the borrower citizen for the personal, family, house or other use which is not connected with business activity; 2) the right to challenge the loan agreement on its lack of money; 3) the right to demand acceptance of appropriate execution; 4) the right to demand to issue it the voucher of execution completely or in the corresponding part or to return the debt document, and at impossibility of return to point to it in the receipt issued to them; 5) the right for free execution of the liability under the contract of a consumer loan; 6) the right to forbid a concession the creditor to the third parties of the rights (requirements) for the contract of a consumer loan; 7) right for refusal of the conclusion of additional contracts; 8) the right for refusal of receiving the additional services connected with the contract of a consumer loan; 9) the right for the free choice of contractors concerning additional services. Under the contract of a ware loan the borrower has rights connected with granting things to it in the coordinated quantity, the range, completeness, quality, a container and (or) packing. The lessor has the following rights: 1) to demand return of the sum of a loan; 2) payments of the due percent for use of a loan; 3) to exercise control of target use of the loan issued on definite purposes; 4) to receive the due percent in case of the compelled early cancellation of the contract because of the violation allowed by 
the borrower; 5) to concede to the third parties of the right (requirement) for the contract of a consumer loan; 6) to refuse delivery of a consumer loan.

Under the contract of a monetary loan and under the contract of a ware (commodity) loan of the party have the differing set of the rights which are subject to protection different forms, means and in the ways. If subject of the contract of a loan is the thing, the borrower has the rights granted to the buyer under the contract of purchase and sale concerning quantity, the range, completeness, quality, a container and (or) packing of the provided things

\section{CONCLUSIONS}

The rights of the loan agreement parties can be classified on precontractual and contractual; on the rights connected with emergence, execution and termination of the contract of a loan; on the property and non-property rights. Separately it is necessary to mark out the information rights of the borrower.

It is concluded that it's conceivable to decide that rules of article 822 Civil Code of the Russian Federation about amount, about the range, about culmination, about quality, about a holder as well as about pressing of the gave things are dependent upon application and to the advance understanding of things.

Modern regulation of the loan agreement is based on standards of the Russian pre-revolutionary legislation and the pre-revolutionary doctrine that allows using the legal designs developed during the pre-revolutionary period by science and practice. In particular, in the pre-revolutionary doctrine an opportunity to sign the loan agreement on consensual model in this connection we consider that this legal design can be reproduced in the existing civil legislation was proved. 


\section{ACKNOWLEDGEMENTS}

The work is performed according to the Russian Government Program of Competitive Growth of Kazan Federal University.

\section{REFERENCES}

Arslanov, K. M. (2016). About bilaterally binding character of the loan agreement. In The Seventh Perm congress of scientists-lawyers: materials of the Russian International Practice Conf. (18-19 Nov. 2016). Perm, 85-87.

Braginsky, M. I. (2006). Contract law. In Braginsky, M. I., \& Vitryansky, V. V. Book 5, t. 1, Contracts on a loan, bank credit and factoring. The contracts directed to creation of collective educations. Statute, 734 pages.

Givil law: textbook in 3 t. (2017). Under the editorship of A. P. Sergeyev. M, Prospectus, T. 2. 880 pages.

Givil law: textbook. (2017). in 2 t. under the editorship of B. M. Gongalo. T.2. M, 543 pages.

Givil law: the textbook. (2006). Under the editorship of the doctor of jurisprudence, professor O. N. Sadikov. T. 2. M. "Contract", "INFRA-M", 608 pages.

Corbin, A. (1918). New Contract By A Debtor to Pay His Pre-existing Debt. Yale Law fournal. 19171918, 27, 535-539. http://www.jstor.org/stable/786344

Dale, W. (1977). Legislative drafting: a new approach: a comparative study of methods in France, Germany, Sweden and The United Kingdom. Butterworths. https://doi.org/10.1017/S0008197300093041

Davies, P. (2016). Rectification versus Interpretation: The Nature and Scope of the Equitable Jurisdiction', CLF, 75, 62-85. https://doi.org/10.1017/S0008197315000975 
Fedulina, E. V. (2015). Civil Protection of the Rights of the Borrower under the Contract of a Consumer Loan (Loan): Law Sci. (PhD Thesis), 207 pages.

Karapetov, A. G. (2012). Freedom of the contract and its limits. T. 2: Limits of freedom of definition of terms of the contract in foreign and Russian law. A.G. Karapetov, A. I. Savelyev. M.: Statute, 453 pages.

Khabirov, A. I. (2013). Protection of interests of citizens-consumers in the obligation regarding return of a monetary debt. Collection of postgraduate scientific works of Law department. KFU, (14), 535-539.

Khabirov, A. I. (2014). To the question of abuse of the right of the lessor according to the loan agreement. Collection of postgraduate scientific works of law department of $K(P)$ FU. Kazan, (15), 127-132.

Khabirov, A. I. (2017). About value of historical development for formation of modern institute of a loan. Civil law, 3, 36-39.

Law, C. (2015). An Introduction to the Comparative Method of Legal Study and Research. By Gutteridge.

Lupu, A. A., \& Whether, I. I. (2011). Zakonna activity of the collection agencies? Economy and right, 3, 102.

Marandi, M., Saadat, S. S. B., Gheis, Z. S., \& Bahari, H. (2015). Analytical studi the rules on bankruptcy and refined in the commercial code. Fournal of Social Sciences and Humanities Research, 6(03), 1-4. https://en.civilica.com/Paper-JR_UJSSHR-JR_UJSSHR-3-1_025=Analytical-studithe-rules-on-bankruptcy-and-refined-in-thecommercial-code.html

Melo, R., Bezerra, M. C., Dantas, J., Matos, R., de Melo Filho, I. J., Oliveira, A. S., \& Maciel, P. R. M. (2017). Sensitivity analysis techniques applied in cloud computing environments. In 2017 12th Iberian Conference on Information Systems and Technologies (CISTI) (pp. 1-7). IEEE. https://doi. org/10.23919/CISTI.2017.7975950 
Meyer, D. I. (2003). Russian civil law [An electronic resource]: in 2 h / D. I. Meyer. M.: Statute. http:// civil.consultant.ru/elib/books/45

Novgorod, V. (2017, April 18). State Council Presidium meeting on the development of a national consumer protection system. President of Russia. http://www.kremlin.ru/events/president/news/54328/videos

Romanets, Y. V. (2013). System of contracts in civil law of Russia. 2nd prod., Re-ed. and additional M.: Norm: Infra-M, $496 \mathrm{p}$.

Russian civil law: textbook: in 2 t. (2011). Editor E. A. Sukhanov. M.: Statute, T. 2: Liability law. 1207 pages.

Rybakova, S. V. (2012). What new the civil code in regulation of the credit relations will introduce? Bank right, 5, 34-40.

Shvachko, N. A. (2012). Problem of recognition of the credit agreement with participation of the consumer contract of accession. Lawyer of Higher Education Institution, 6, 59-64.

Siems, M., \& Síthigh, D. M. (2012). Mapping legal research. The Cambridge Law Journal, 71(3), 651676. https://doi.org/10.1017/S0008197312000852

Vishnevsky, P. N. (2015). Legal regulation of the contract of the international loan: Law Sci. (PhD Thesis), 25 pages. 